\title{
UN VIATGE PEL CINEMA DE CIÈNCIA FICCIÓ
}

\author{
Agustí Salvat Altés. Àrea de Didàctica de les Ciències Experimentals. URV
}

\section{Introducció}

Ja fa uns anys que la utilització de la ciència ficció com a eina d'estudi, treball i ensenyament és un fet a diverses universitats anglo-saxones. L'any 1959 Thomas Clareson creava a la universitat de Kent (Ohio, EUA) la primera revista acadèmica que se centrava en la ciència ficció. Es tracta d'Extrapolation, que va ser la pionera d'altres revistes semblants com Foundation o Science Fiction Studies. El moviment va agafar tanta embranzida que l'any 1970, Thomas Clareson fundà la Science Fiction Research Association (SFRA, associació de recerca sobre la ciència ficció) amb objectius tan clars com "l'estudi de la ciència ficció i la fantasia, la millora de l'ensenyament a les aules, l'avaluació de nous llibres i de nous mètodes i materials per a l'ensenyament". La iniciativa fou un èxit, ja que actualment formen part de la SFRA uns quants centenars de professors d'arreu del món.

Encara que la majoria d'activitats acadèmiques universitàries al voltant de la ciència ficció tingueren, en un primer moment, un caire que es podria anomenar de lletres o marcadament literari, actualment moltes universitats han incorporat la ciència ficció als seus currículums de ciències. A títol d'exemple, pot citar-se el cas de la Universitat Politècnica de Catalunya: des del curs 1993/94, els professors Jordi José i Manel Moreno ofereixen un curs sobre Física i ciència ficció en el marc de les noves assignatures de lliure elecció. Actualment aquesta assignatura està consolidada i les places ofertes resulten insuficients davant la forta demanda dels estudiants.

L'ús adequat de films i llibres de ciència ficció (MORENO, 1999; JOSÉ, 1996)) com a material didàctic pot ser de gran ajut en l'aprenentatge de la ciència. En primer lloc, els principis físics il-lustrats (i sovint violats) es poden introduir d'una forma més suggestiva a través de la ciència ficció. Així, els conceptes abstractes són directament visualitzats, de manera que el formulisme matemàtic associat resulta més fàcil d'entendre i d'assimilar. D'altra banda, la visió de fragments de pel.lícules ajuda a distingir la ciència de la pseudociència, malauradament tan arrelada. Alhora, serveixen per capgirar les actituds negatives cap a la ciència vertadera i desperten un saludable esperit crític i escèptic.

Aquest treball que ara presentem veié la llum per primera vegada en format de cine fòrum a les Primeres Jornades de Mestres de Tarragona (2002), i posteriorment, amb lleugeres variacions, a la Sisena Setmana de l'Ensenyament de Terrassa (2002).

\section{Compte amb les formigues!}

Les formigues mutants de 10 metres que surten a la pel.lícula La humanidad en peligro (Them!, 1954) són el resultat de l'exposició de formigues comunes a la radiació ionitzant causada per les proves atòmiques realitzades al desert d'Arizona pels militars nord-americans. A banda de dedicar-se a robar una gran quantitat d'aliments, especialment de sucre, s'enfronten als éssers humans $i$ avancen de forma imparable fins a la ciutat de Los Angeles.

El que cal preguntar-se és si aquestes formigues gegants són viables en la realitat. La resposta és negativa. Vegem-ne el motiu.

\section{Llei quadrat/cúbic de Galileu (1564-1642)}

Fa més de tres segles que Galileu va enunciar aquesta llei d'escala, que estableix que: "Quan un objecte creix sense canviar de forma, la seva superfície augmenta com el quadrat d'una longitud característica del cos (l'altura, per exemple), mentre que el volum ho fa com el cub". Com que hi ha propietats físiques d'un cos que depenen del volum i d'altres, de la superfície, les que depenen del volum creixen més de pressa amb l'augment de la dimensió que les que depenen de la superfície. Per tant, una variació de volum comportarà, sovint, diferències notables.

Per clarificar-ho, suposem que fem créixer proporcionalment un cub d' 1 metre d'aresta i d' $1 \mathrm{~kg}$ de massa, fins que tingui $10 \mathrm{~m}$ d'aresta. La relació entre l'aresta del cub gran i la del cub petit és el que s'anomena factor d'escala i, en aquest cas, val 10 (Fig. 1).

El pes del nou cub serà $1000 \mathrm{~kg}$. És a dir, el pes ha crescut com el cub del factor d'escala. La superfície de

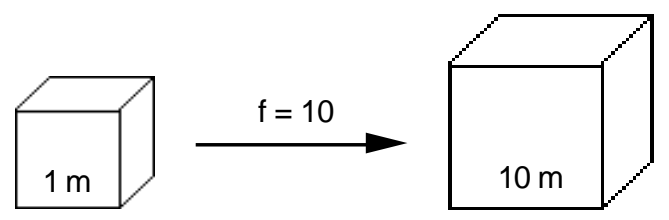

Figura 1. Factor d'escala 


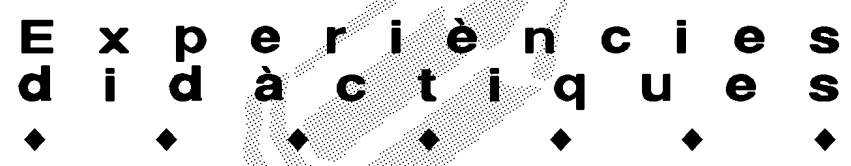

la base serà de $100 \mathrm{~m}^{2}$. Per tant, la superfície només haurà crescut com el quadrat del factor d'escala.

Si tenim en compte que la pressió sobre la base del cub (relació entre el pes i la superfície) és $1 \mathrm{~kg} / \mathrm{m}^{2}$, al cub gran la pressió serà de $10 \mathrm{~kg} / \mathrm{m}^{2}$. És a dir, la pressió només haurà crescut com el factor d'escala.

Tornant a les formigues, podem estimar el pes d'una formiga gegant a partir de la grandària d'una formiga real (1 cm, aproximadament) i de la seva massa: $1 \mathrm{~g}$, aproximadament. Com el factor d'escala de l'ampliació és: $10 \mathrm{~m} / 1 \mathrm{~cm}=1000 \mathrm{~cm} / 1 \mathrm{~cm}=1000$, la formiga gegant serà $1000^{3}$ vegades més pesant. És a dir, tindrà un pes de 1000 tones.

En una formiga real, la pressió que aguanta cadascuna de les sis potes es pot determinar a partir de l'estimació del diàmetre d'una pota: $1 \mathrm{~mm}$. La pressió és: $0,17 \mathrm{~g} / \pi(0,5 \mathrm{~mm})^{2} \approx 0,2 \mathrm{~g} / \mathrm{mm}^{2}$. En una formiga gegant, la pressió sobre cadascuna de les seves potes serà: $1,67.10^{8} \mathrm{~g} / \pi(500 \mathrm{~mm})^{2} \approx 210 \mathrm{~g} / \mathrm{mm}^{2}$. A l'augmentar de grandària, la pressió que han de suportar les potes de l'animal gegant ha augmentat en un factor: $210 / 0,2 \approx 1000$. Aquesta formidable pressió seria equivalent a la que hauria de suportar una persona que hagués d'aguantar el pes de 1000 persones col-locades damunt seu. És evident que una formiga d'aquestes dimensions seria inviable, ja que s'esfonsaria sota el seu propi pes.

La força relativa que pot realitzar un animal depèn de la secció transversal dels seus músculs. Recordem, per exemple, que un aixecador de pes ha de tenir uns braços i unes cames de secció gran. Es defineix la força relativa d'un animal com el quocient entre el pes que pot aixecar, que és el mateix que la força que pot fer, i el seu propi pes:

$$
\text { Força relativa }=\frac{\text { pes que pot aixecar }}{\text { pes de l'animal }}
$$

Com que el numerador depèn de la secció transversal dels seus músculs (que és proporcional al quadrat d'una longitud característica com la seva altura, per exemple) i el denominador depèn del cub de l'altura, resulta que la força relativa és inversament proporcional a l'altura de l'animal. És a dir, si comparem dos animals semblants geomètricament, el més gran sempre té una força relativa menor. És més feble!

Com a illustració del que s'acaba de dir es pot posar l'exemple de la formiga i de l'home. Una formiga té una força relativa igual a 3, mentre que en l'home la força relativa mitjana té un valor pròxim a 1 . Dient-ho d'una altra forma: La formiga pot aixecar tres vegades el seu propi pes. L'home, només el seu pes (excepte els que es dediquen a l'halterofília).

I la formiga gegant, quina força relativa té? La relació entre la força relativa de la formiga gegant $\left(\mathrm{Fr}_{\mathrm{g}}\right)$ i la de la formiga real $\left(F r_{r}\right)$ és inversament proporcional al factor d'escala (1000). Com que $\mathrm{Fr}_{r}$ val $3, \mathrm{Fr}_{\mathrm{g}}$ té un valor de 0,003 . Per tant, la formiga gegant només pot aixecar un 3 per 1000 del seu propi pes. Possiblement no podria aixecar ni les seves potes per caminar. Seria un animal patèticament grotesc.

La formiga gegant encara té més inconvenients: Si no morís aixafada, moriria d'insuficiència respiratòria o renal, ja que, mentre la quantitat de teixit cel.lular amb necessitat d'oxigen creix amb el cub de la longitud de l'animal, la capacitat d'absorció d'oxigen per part dels pulmons només creix amb la seva superfície, és a dir, amb el quadrat de la longitud de l'animal. El mateix argument pot aplicar-se al funcionament dels ronyons, que actuen com a filtres sanguinis.

\section{Monstres impossibles: El bestiari imaginari de la ciència ficció}

Amb els arguments tan senzills que s'han fet servir per al cas de la formiga gegant -basats en les lleis d'escala-, es pot qüestionar la realitat física de la majoria

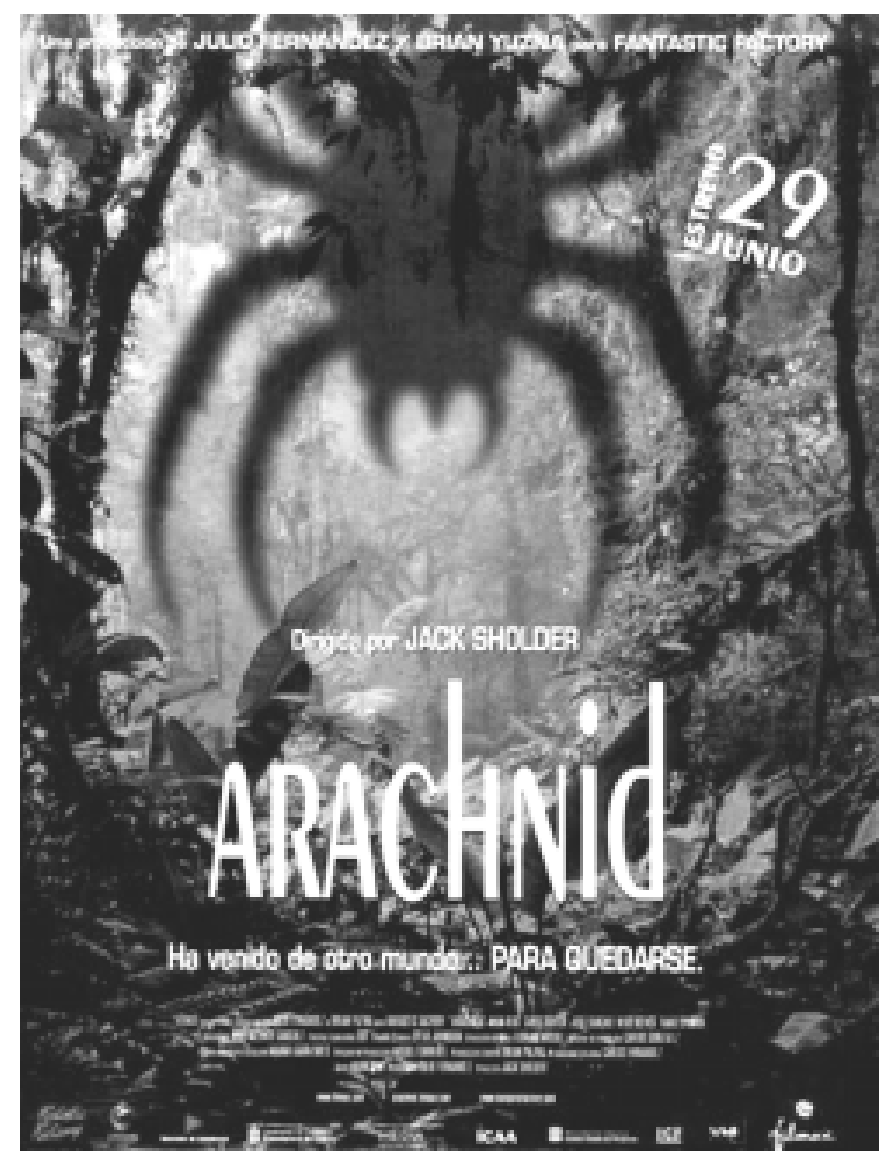

Poster del film Arachnid, 2001 


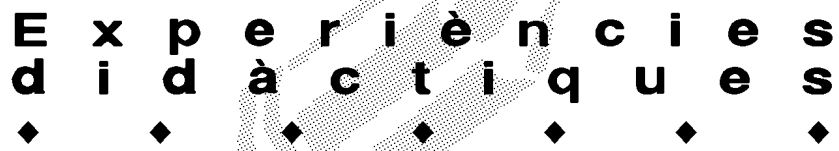

dels éssers colossals de l'aparador dels mites del cel-luloide, ja que no tenen -mai millor dit- cap mena de suport real.

L'enamoradís goril.la de la pel-lícula King Kong (1933), amb una alçada de $18 \mathrm{~m}$ i 130 tones de massa (factor d'escala igual a 8 ), difícilment podria ser tan àgil com per escalar un gratacels, tal i com es mostra a la memorable escena final del film (Fig. 2).

Godzilla, un dels monstres més famosos de tots els temps -amb el permís de King Kong-, és un dinosaure amfibi mutant capaç, com els mitològics dragons, d'emetre foc per la boca. El temible monstre japonès, de $120 \mathrm{~m}$ d'altura i 20000 tones de massa en la versió americana (Godzilla, 1988), es mou a una velocitat i amb una agilitat tan grans pels carrers de Nova York que arriba a confondre els àgils helicòpters que el persegueixen.

La teranyina formada per les aranyes és àmplia i diversa. Tarántula (1955), amb una aranya que creix al laboratori del professor Deemer fins a convertir-se en un monstre de $8 \mathrm{~m}$ de diàmetre (factor d'escala igual a100). A The Giant Spider Invasion (1975) es veu com el trànsit d'un microforat negre obre una porta d'accés a un altre univers paral.lel, des del qual sorgeixen gegantines aranyes de 15 metres de diàmetre (factor d'escala igual a 200), que tenen atemorida una tranquil.la població de Wisconsin (EUA). A Arachnid(2001), de la productora barcelonina Fantastic Factory, l'aranya alienígena, tal i com diu el cartell publicitari de l'estrena: "Ha venido de otro mundo... para quedarse!". El que potser no sap és que amb les dimensions tan impressionants que té, ha d'haver vingut d'un món on el camp gravitatori sigui molt fleble. I quan arribi al nostre, amb un camp gravitatori intens, es quedarà... aixafada pel seu gran pes!

L'estiu passat la teranyina augmentà de grandària, ja que s'estrenà Arac Attack (2002) i Spiderman (2002).

La resta del zoològic és un ventall ampli i divers. L'argument que explica la diversitat d'éssers descomunals acostumen a ser misterioses radiacions o sorprenents fertilitzants. S'hi troben pops (It Came from Beneath the Sea, 1955); crancs (Attack of the Crab Monsters, 1957); llagostes ( The Beginning of the End, 1957); mantis religioses (E/monstruo alado [The Deadly Mantis, 1957]); sangoneres (Attack of the Giant Leeches, 1960); pterodàctils gegants (Radon, 1965); arnes (Mothra, 1964); rates (El alimento de los dioses [The Food of the Gods, 1976])... Extraordinaris éssers que, generalment, prefereixen perseguir valentes -i guapes- heroïnes.

Els gegants humans també tenen el seu racó dins el zoològic. El coronel Manning, l'humà exposat accidentalment a la radiació atòmica, creix a un ritme d'1,5 m diaris i es converteix en E/ gigante ataca (The Amazing Colossal Man, 1957), un gegant de més de $18 \mathrm{~m}$ d'altura.
Tampoc la rèplica femenina del coronel Manning, l'atractiva senyora Archer de la pel.lícula El ataque de la mujer de $15 \mathrm{~m}$ (Attack of the $50 \mathrm{ft}$. Woman, 1958), amb una reeditada versió de l'any 1994, no té cap possibilitat real, per molt que el gegantisme d'aquesta senyora s'hagi provocat per l'encontre amb un ovni. Finalment, a la versió infantil de la dona gegant (Attack of the 60 Foot Centerfold, 1995), la fèmina de torn ha guanyat en atractiu i en altura.

\section{Homes microscòpics que surten de la rentadora}

Si la vida, a l'imaginari món dels monstres gegantins, resulta inviable, la reducció d'éssers humans a escala microscòpica presenta un seguit d'inconvenients que també els fan inviables. A la pel-lícula E/ chip prodigioso (Innerspace, 1987) -que és una paròdia de Viaje alucinante (Fantastic Voyage, 1966) - un tinent de les forces aèries nord-americanes se sotmet a un experiment: el miniaturitzaran amb el seu submarí de butxaca per introduir-lo a l'interior d'un conill de laboratori. El miniaturitzador emprat funciona a base de fer girar molt ràpidament el submarí fins a aconseguir que totes les seves parts, incloent-hi el protagonista que el pilota, es redueixin fins a una dimensió adequada per viatjar sense problemes per l'interior del conill. La ràpida rotació sembla que provoca l'efecte miniaturizador desitjat, al facilitar el col-lapse de l'objecte. Idea errònia, ja que tothom que ha pujat a una atracció rotatòria de fira ha pogut comprovar la "tendència" a allunyar-se de l'eix de rotació i no a apropar-s'hi! Aquesta "tendència" és provocada per una interacció anomenada força centrífuga. En el supòsit que el material del submarí fos capaç de no esbocinarse per les tremendes forces involucrades en la rotació que es mostren a la pel-lícula, en lloc d'aconseguir la miniaturització desitjada el que es tindria és un pilot en un estat més que lamentable per culpa de la tremenda acceleració centrípeta a la qual l'hauríem sotmès.

En el cas que el miniaturitzador-rentadora aconseguís el seu propòsit, és adir, reduir el submarí a escala microscòpica $\left(f=1 / 10^{7}\right)$, ens hauríem de preguntar on ha anat a parar la massa que ha sobrat. Sota quin mecanisme hauria de funcionar l'hipotètic miniaturitzador? D'entrada, tres mètodes permeten dotar d'una certa base física les suposades disminucions de grandària: 1) Un major apilotament dels àtoms del cos. 2) Desaparició d'una part dels àtoms de cada part del cos. 3) Contracció dels àtoms. Les dues primeres opcions es poden descartar ràpidament. En el primer mètode, les altes pressions involucrades en el procés acabarien amb la vida del protagonista abans d'assolir la mida desitjada. La segona opció planteja un dilema interessant: Quins àtoms es descarten?, els no vitals? I quan 


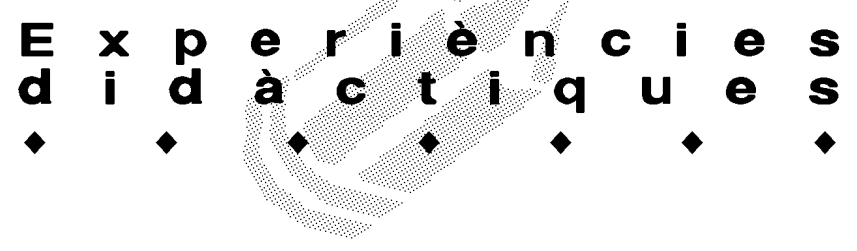

arribem al cervell, què fem? Davant la tercera solució es plantegen dues noves possibilitats: a) Les masses dels àtoms romanen invariables, $i$ b) Les masses disminueixen de forma directament proporcional al seu volum. En les condicions de l'apartat a), la densitat de l'home miniatura seria $\left(10^{7}\right)^{3}=10^{21}$ vegades superior a la d'una persona normal, que posseeix una densitat mitjana semblant a la de l'aigua. Es tindria un tipus de matèria tan compacta que fins i tot resultaria més densa que la que forma una estrella de neutrons. El microhumà, dins del seu microsubmarí, foradaria el terra del laboratori i s'enfonsaria, perforant l'escorça terrestre, fins a arribar al centre de la Terra. No sembla, doncs, un bon mètode per fer-se petit. Si s'opta per l'opció b), també hi ha inconvenients. Una reducció de massa significa que aquesta es perd. Si es perd, on va a parar? Només es coneix una forma de fer desaparèixer massa, i és que es transformi en energia. Aquesta conversió de massa en energia és extraordinàriament eficient $\mathrm{i}$ constitueix el fonament de les bombes atòmiques. En això és en el que, possiblement, es convertiria l'intrèpid protagonista.

\section{Diàlegs impossibles: La parla dels nans}

A banda dels problemes que tindria el micronauta pel fet d'haver reduït la seva grandària de forma considerable, i que ja s'han indicat a l'apartat anterior, també tindria greus inconvenients per comunicar-se amb els humans de dimensions normals.

Les cordes vocals dels animals, i també les de l'home, produeixen les vibracions de l'aire que donen lloc a la parla. Les cordes vocals són petits músculs la tensió dels quals es pot variar a voluntat. Es poden assimilar aproximadament a una corda tibant que vibra. Si la tensió i la densitat de la corda es mantenen constants, la freqüència de vibració de la corda resulta ser inversament proporcional al quadrat de la seva llargada. I com que la llargada de la corda vocal està relacionada amb la grandària de l'animal, la freqüència de vibració $\left(f_{v}\right)$ resulta inversament proporcional al quadrat de la mida de l'animal (L):

$$
f_{v}=\frac{1}{L^{2}}
$$

Malgrat el senzill model utilitzat, les freqüències que se'n deriven concorden qualitativament amb les dels sons emesos per bona part dels animals. S'ha observat que com més gran és l'animal, més greu és la seva veu. En la parla humana, la gola i les cavitats bucal i nasal actuen com a estructures ressonants que s'encarreguen de ressaltar unes freqüències i d'atenuar-ne unes altres, i donen lloc a una notable varietat de sons. La freqüència fonamental de la veu de l'home és d'uns $150 \mathrm{~Hz}$, i de
$250 \mathrm{~Hz}$ en la dona.

Als intruments musicals de la mateixa família també es pot apreciar aquest efecte. El violoncel té un so més greu que un violí perquè el primer té les cordes més llargues que el segon.

Segons el que s'acaba de dir, quina seria la freqüència de la veu emesa pel micronauta de El chip prodigioso (Innerspace, 1987) quan parla amb els humans normals de la sala de control?

La relació entre les freqüències de la veu del micronauta $\left(f_{m}\right)$ i de la veu dels humans de dimensions normals $\left(f_{n}\right)$ és:

$$
\frac{f_{m}}{f_{n}}=\frac{\frac{1}{L_{m}^{2}}}{\frac{1}{L_{h}^{2}}}=\frac{L_{h}^{2}}{L_{m}^{2}}=\left(\frac{L_{h}}{L_{m}}\right)^{2}=f^{2}
$$

on frepresenta el factor d'escala.

En conserqüència, la freqüència de la veu del micronauta és:

$$
f_{m}=f_{n} \cdot f^{2}=150\left(10^{7}\right)^{2}=1,5 \cdot 10^{16} \mathrm{~Hz}
$$

Aquesta freqüència correspon a la regió dels ultrasons i cau fora de l'interval d'audibilitat dels humans de dimensions normals, ja que les freqüències que l'oïda humana pot percebre (per a un nivell d'intensitat de so suficient) se situen entre 18 i $20000 \mathrm{~Hz}$.

Val a dir que els guionistes de la pel-lícula no han tingut en compte l'efecte del canvi de freqüència amb la grandària del micronauta, ja que si ho haguessin fet, bona part de la pel.lícula seria muda per als espectadors. De fet, l'efecte analitzat sí que s'ha tingut en compte a la seqüència on els "dolents" són reduïts a la meitat de la seva grandària, perquè parlen amb una veu més aguda.

\section{Ascensors galàctics}

De sobte es disparen les botzines d'alarma de la nau USS Enterprise. El capità Kirk es dirigeix ràpidament a la sala de control del teletransportador, però només és a temps de veure com els teletransportats moren a conseqüència d'una fallada d'energia durant l'operació de reintegració dels seus cossos (Star Trek, la película: la conquista del espació[Star Trek - The Motion Picture, 1979]).

Sense tenir en compte la limitació imposada per l'abast del teletransportador, el teletransport presenta una dificultat insalvable quan s'analitza el volum d'informació involucrada en el fenomen. El cos humà conté uns $10^{28}$ àtoms. Per a cada un d'ells es necessiten tres coordenades per a fixar la posició, més una llarga llista d'informació suplementària relativa a velocitats, spins, estats de vibració, etc... Es pot estimar en un kilobyte la informació necessària per identificar amb exactitud l'estat 


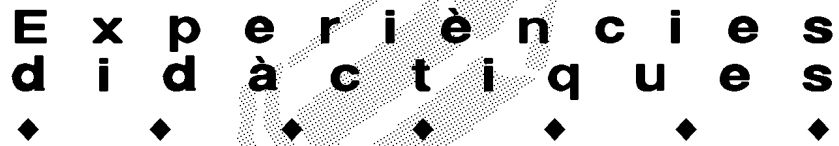

de cada àtom del cos. Per tant, s'han d'enviar uns $10^{28}$ kilobytes d'informació. Es necessitarien uns $10^{21}$ discos durs de 10 gigabytes per emmagatzemar tota la informació. Amb un gruix de l'ordre d'1 $\mathrm{cm}$ per disc, la informació relativa a un sol cos humà formaria una pila de discos de 1000 anys llum d'altura, aproximadament unes 200 vegades la distància que ens separa d'Alfa Centaure, l'estrella més propera a nosaltres.

$\mathrm{Si}$ es pogués prescindir-que no es pot- de tots els problemes tècnics relatius al emmagatzemament de la informació, ens podríem centrar en els aspectes relatius al temps necessari per enviar tota la informació. Els dispositius comercials més ràpids de transferència de la informació operen al voltant d'un gigabyte per segon. A aquest ritme es necessitarien uns $10^{22}$ segons per processar la informació continguda en un ésser humà, aproximadament unes 20000 vegades l'edat de l'univers. I això només per enviar la informació. La seva obtenció, l'emmagatzemament en un suport físic, l'enviament i la posterior recepció, augmentarien considerablement la xifra.

El teletransport comporta l'existència d'un emissor, responsable dels procesos de desintegració, codificació i transmissió del senyal, i d'un receptor, destinat a la recepció i reintegració de la informació. Així, mentre el teletransport entre naus de la Federació Galàctica és viable sempre que no se superin els $40000 \mathrm{~km}$ (abast dels teletransportadors), no s'explica com una nau pot enviar un equip d'exploradors a un planeta que no ha estat prèviament visitat $\mathrm{i}$, per tant, no posseeix cap receptor, com es pot veure a Star Trek III: en busca de Spock (Star Trek III: the Search for Spock, 1984).

\section{Una mica de llum sobre la llum}

Els petits caces del reduït grup rebel que lluiten per retornar la llibertat a la galàxia s'enfronten a les naus de I'Imperi Galàctic per tal d'abatre la temible Estrella de la Mort, l'estació espacial cuirassada capaç de destruir un planeta sencer (El retorno de/ Jedi [Return of the Jedi, 1983]). La seqüència és un esclat de so, llum i color que res té a envejar dels espectacles pirotècnics nocturns de Port Aventura.

El que no s'ha tingut en compte és que a l'espai buit (sense aire ni cap mena de gas) els caces imperials no poden fer les acrobàcies "aèries" que fan, ja que cal el fregament amb l'aire; el disseny aerodinàmic dels caces

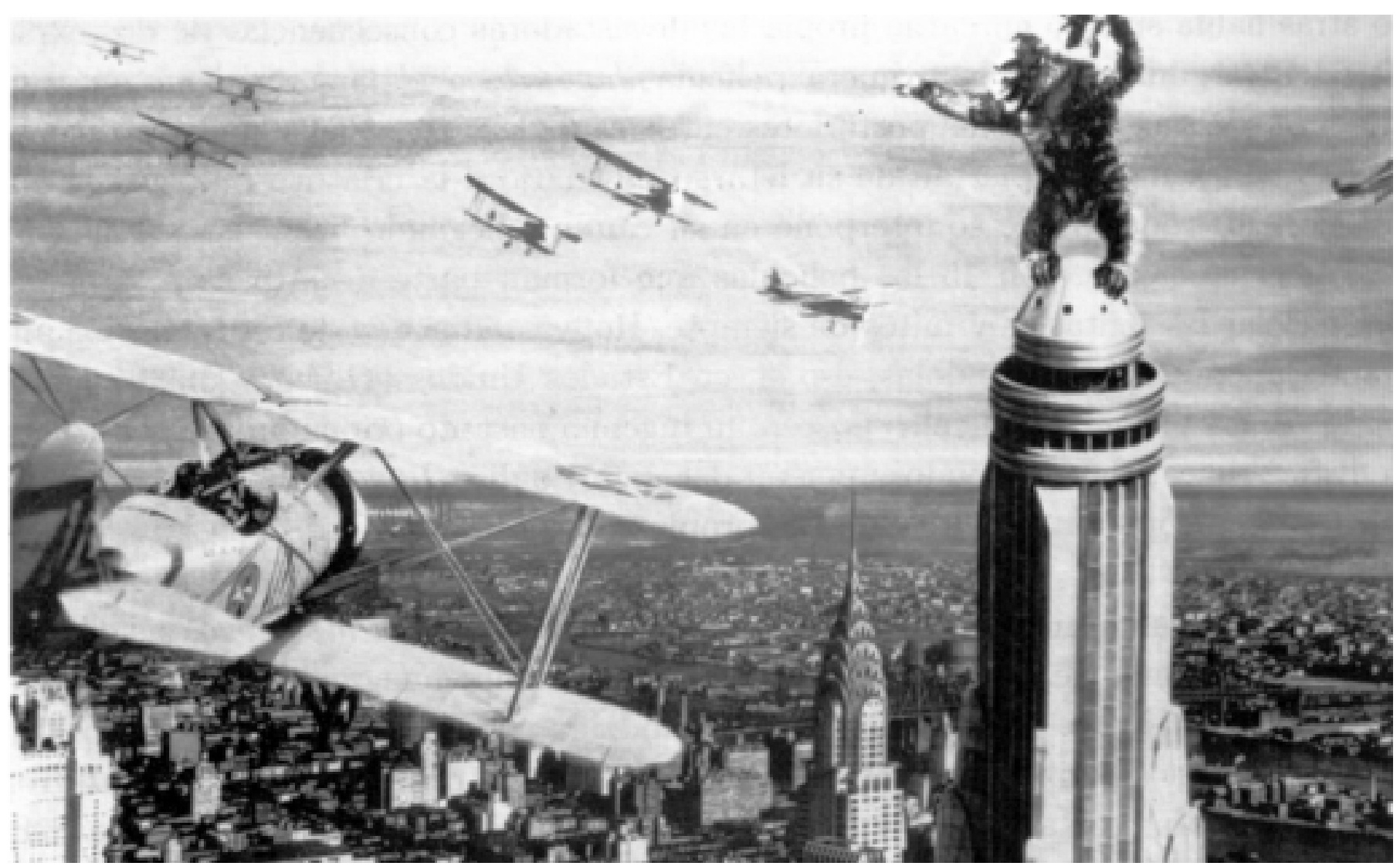

Figura 2. L'incomprès King Kong enfrontant-se als intolerants humans a la pel-lícula King Kong(1933) 


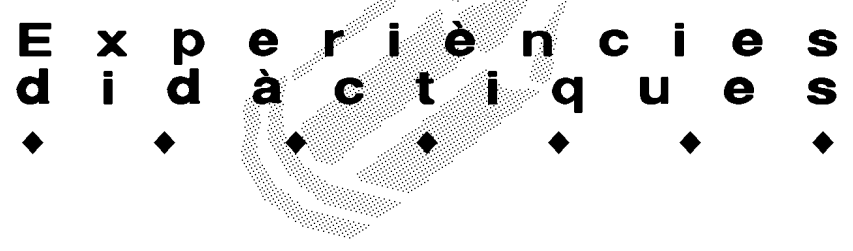

i de la resta de naus involucrades en la batalla és absurd, precisament per la manca de resistència en no haver-hi fregament amb l'aire; el zum-zum dels motors de les naus i les explosions durant la batalla no es poden sentir, perquè el so necessita un medi material per a propagar-se.

Pel que fa a les ràfegues de llum que emeten els canons làser dels caces, cal dir que es mouen a velocitat molt més baixa del que s'haurien de moure (300 000 $\mathrm{km} / \mathrm{s}$ ), Si ho fessin així, els espectadors no veurien ràfegues. Respecte al fet de veure el traç de les ràfegues, és impossible, perquè a l'espai buit no hi ha dispersió de la llum en no haver-hi, pràcticament, matèria.

És clar que les batalles espacials, com la descrita anteriorment, sense acrobàcies, sorolls, explosions ni raigs que creuessin d'un costat a l'altre, resultarien poc espectaculars i gens atractives. Cal pensar que, quan els guionistes i escriptors cometen aquests errors de física elemental, ho fan de forma deliberada per donar més força a l'espectacle cinematogràfic.

En una seqüència de La guerra de las galaxias (Star Wars, 1977), Obi wan Kenobi, un antic cavaller Jedi, s'enfronta al malèvol Darth Vader o Senyor del Sith, un excavaller Jedi que s'ha aliat amb l'Imperi Galàctic per tenir el control absolut de la galàxia. Obi wan agafa el seu sabre i un potent raig làser de color blau verdós surt de la base de l'empunyadura i ascendeix lentament fins a assolir una llargada pròxima a un metre. Immediatament s'inicia l'espectacular duel de sabres amb el Senyor del Sith.

El que resulta inversemblant és que el raig làser del sabre d'Obi wan es mogui a una velocitat tan lenta quan s'engega el sabre, que s'aturi quan assoleix una determinada longitud sense que hi hagi cap obstacle material que provoqui la seva aturada i que se senti el xoc dels dos raigs làser en el decurs del duel com si es tractés del xoc de dues espases metàl-liques.

\section{La invisibilitat}

Entre els somnis i anhels de l'home (volar com els ocells, l'eterna joventut, ser immortal...) s'inclou també la invisibilitat. A la novel-la de H.G. Wells (1897), un científic, Jack Griffin, s'injecta durant un mes una dosi diària d'un preparat, la monocaïna, que conté, entre altres productes, una substància utilitzada per blanquejar teixits. Conscient del seu fabulós poder, esdevé, a part d'invisible, un maníac que vol dominar el món cometent tot tipus de malifetes amb absoluta impunitat (Fig. 3). Amb el cos recobert de benes, intenta dissimular la seva singular naturalesa, encara que, finalment, el rastre deixat per les seves petjades sobre la neu permeten a la policia anul-lar la seva prometedora carrera de brètol ( $E$ ) hombre invisible [The Invisible Man, 1933]).

Una versió moderna de l'home invisible la trobem a El hombre sin sombra (The Hollow Man, 2000). Entre ambdues pel-lícules hi ha més de trenta versions cinematogràfiques diferents sobre el mateix tema. Algunes de destacades són: El retorno del hombre invisible (The Invisible Man Returns, 1939), La mujer invisible (The Invisible Woman, 1940), Agente invisible(Invisible Agent, 1942) y La venganza del hombre invisible (The Invisible Man's Revenge, 1944).

Un dels problemes més greus que hauria d'afrontar l'home invisible seria la seva incapacitat per obtenir informació lluminosa. Dit d'una altra manera, l'home invisible seria cec. Si els ulls fossin invisibles, com la resta del cos, haurien de ser transparents, incolors i tenir un índex de refracció pròxim al de l'aire $(n=1)$. En aquestes condicions la llum els travessaria sense ser refractada (Fig. 4). L'ull normal es comporta com una lent de vidre $(n>1)$. Les diferents parts que el constitueixen tenen per missió refractar els raigs de llum, de manera que damunt la retina (focus de la lent) s'obtingui
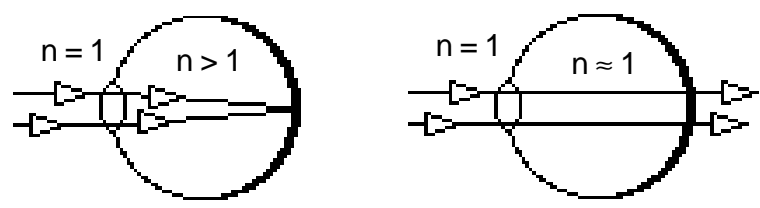

Figura 4. UII normal (esquerra) i ull de I'home invisible (dreta)

la imatge dels objectes de l'exterior. Els raigs de llum no podran convergir en la retina si no existeix refracció. La llum travessarà, doncs, els ulls de l'home invisible sense ser desviada i conseqüentment no es formarà cap imatge.

L'home invisible també tindria altres problemes. En una versió moderna del mite, la pel-lícula Memorias de un hombre invisible (Memoirs of an Invisible Man, 1992), cal destacar els notables efectes especials que mostren ben clarament els problemes que li comportaria la invisibilitat. Per exemple, quan l'home invisible fuma, se li veuen els pulmons. L'home invisible de Wells no podia menjar en públic (s'havia d'amagar fins a haver digerit els aliments), ni vestir-se (la invisibilitat la tenia el seu cos, no els vestits)... i no podia fumar. Inconvenients de la invisibilitat!

\section{Viatges lumínics per l'espai i el temps}

Tot just comença la pel-lícula Superman(Superman, the movie. 1978), quan una petita nau estelada solca l'espai infinit amb rumb al tercer planeta d'un remot sistema solar, un paradisíac món blau anomenat planeta Terra. Durant el viatge el petit Kal-El, fill de Jor-El -un científic del planeta Kriptó que ha descobert la imminent 


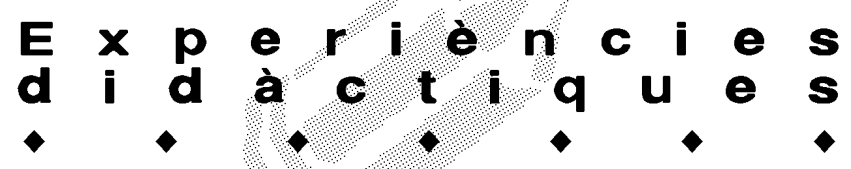

explosió del seu gran Sol- és instruït per les gravacions que li llega el seu pare sobre els costums, hàbits, història i teories científiques dels humans. Entre les teories hi la la de la relativitat d'Einstein, que li permet fer un viatge tan llarg. Quan arriba a la terra promesa, després d'una odissea a través de sis galàxies, Kal-El només ha envellit tres anys: el jove Superman és un petit orfe que serà adoptat pels Kent, però està dotat d'uns immensos poders que ben aviat posarà al servei del seu món adoptiu.

És obvi que la Terra ha de posseir unes característiques especials perquè un científic de Kriptó, un llunyà planeta en la immensitat de l'univers, decideixi escollirla com a bressol del seu primogènit. El pare de Superman havia de ser un veritable entusiasta de les arts, les ciències i les gestes assolides pels humans. No endebades, durant el viatge del petit Kal-El, l'introdueix en el complicat món de la física terrestre. Li parla d'Einstein i de la seva famosa teoria de la relativitat. Malgrat tot, sembla que Jor-El va oblidar algunes de les inquietants implicacions de la seva estimada teoria de la relativitat.

Un dels postulats que Albert Einstein va establir, l'any 1905, amb la teoria de la relativitat restringida, indica que cap cos massiu (com el d'una nau) pot viatjar a una velocitat com la de la llum (c=299 792,454 km/s). Dit d'una altra forma, la velocitat de la llum constitueix un límit superior de velocitats per a qualsevol cos de l'univers conegut. L'univers autorregula el seu propi límit de velocitat i es converteix en la mateixa policia del trànsit galàctic. No existeixen senyals de trànsit a les entrades de les autopistes galàctiques que ens avisin sobre el límit de velocitat permesa, ja que els possibles usuaris mai no podran violar la llei. Es tracta d'un límit natural de l'univers.

La separació entre galàxies no té un valor constant, però es pot prendre un valor mitjà de l'ordre de $1,66 \cdot 10^{19} \mathrm{~km}$. El petit Kal-El va recórrer una distància sis vegades més gran que aquesta en l'etern viatge de Kriptó a la Terra: uns $10^{20} \mathrm{~km}$, aproximadament. Si la llum hagués fet un viatge tan llarg hauria tardat uns $3,34 \cdot 10^{14}$ segons, o el que és el mateix: uns 10,6 milions d'anys. Evidentment, Kal-El va tardar més. En aquella època la Terra era un món poc acollidor. Sobre la seva superfície, poblada només per simis, encara es plorava l'extinció dels dinosaures i l'espècie més intel-ligent, els micos, seguien la llarga cadena evolutiva que desembocaria, uns quinze milions d'anys després, en els primers humans intel-ligents: I'home de Neanderthal. Ens hauríem de treure el barret davant Jor-El, un visionari de primera fila capaç d'explicar la teoria de la relativitat 10,6 milions d'anys abans del naixement d'Einstein i d'enviar el seu fill a un món de simis de forma que, quan hi arribés, ens trobés a nosaltres. Aramis Fuster i Rappel són, al seu costat, uns veritables aprenents!

El límit imposat per la velocitat de la llum obligà

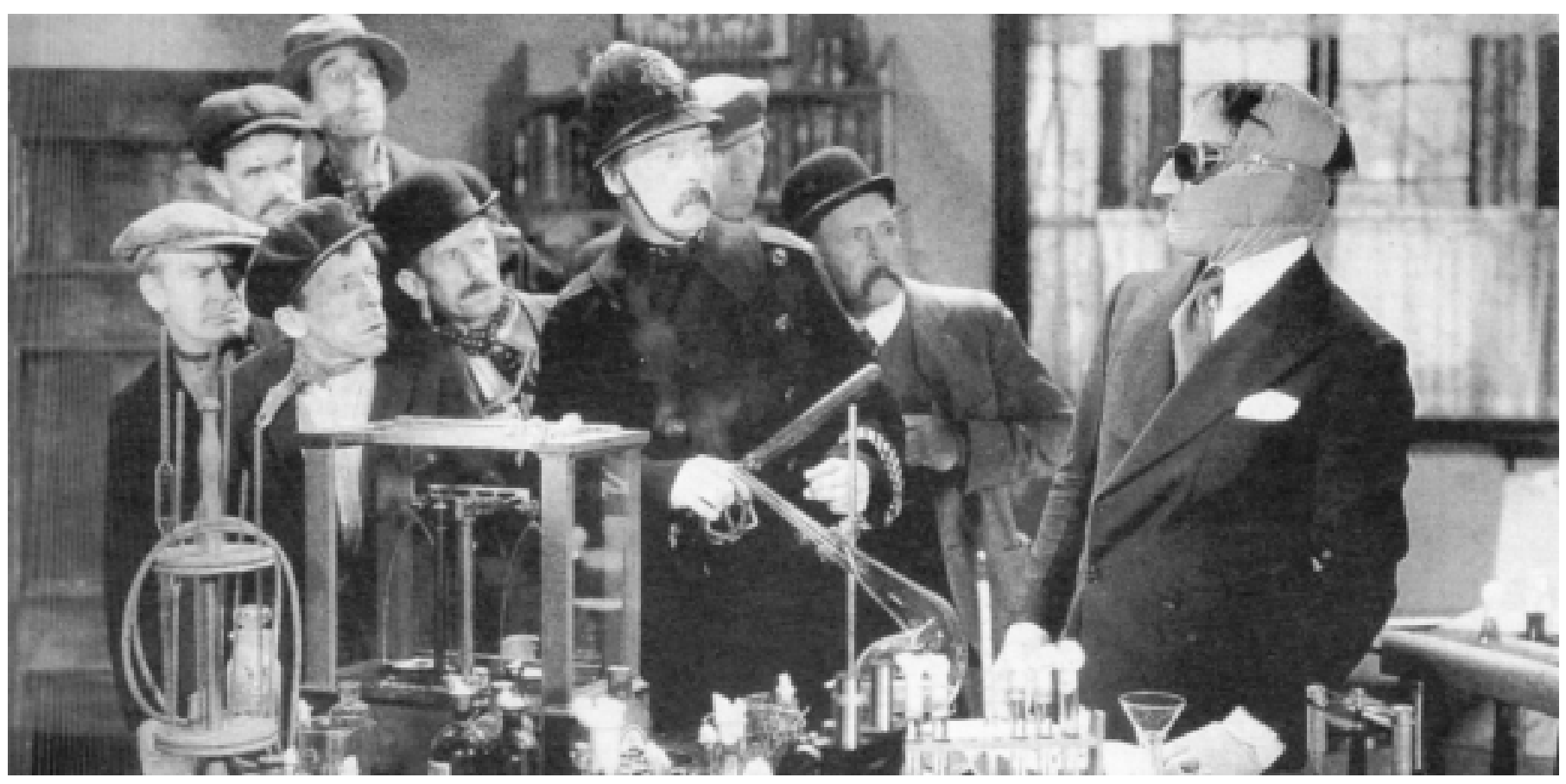

Figura 3. Fotograma de la cinta El hombre invisible [The Invisible Man, 1933], on el protagonista és a punt de descobrir la seva identitat davant els atònits conciutadans 
Einstein a reinterpretar alguns conceptes bàsics de la física clàssica com la longitud, la massa i el temps. El concepte de temps a la relativitat especial sembla extret d'una pel-lícula de ciència ficció. A diferència de la visió clàssica, on el temps és una magnitud constant, el temps passa a un ritme diferent en funció de la velocitat de l'observador. Així, un breu instant de temps, per a un astronauta que s'allunya de la terra a una velocitat propera a la de la llum, es pot traduir en dies, setmanes o... centenars d'anys per als habitants del planeta Terra. Aquesta dilatació del temps, enregistrada tant pels rellotges de la nau com a nivell biològic i psicològic, no solament representa un fenomen aparent, sinó que correspon a un retard real en el ritme amb el qual flueix el temps.

L'interval de temps comprès entre dos successos observats en un mateix lloc s'anomena temps propi ( $\left.t_{0}\right)$. Per a qualsevol observador d'ambdós successos que es manifestin en llocs diferents, segons el seu sistema de referència, l'interval de temps transcorregut entre ambdós (t) sempre serà superior al temps propi.

$$
t_{0}=t \cdot \sqrt{1-\left(\frac{\text { velocitat entre ambdós sistemes }}{\text { velocitat de la llum }}\right)^{2}}
$$

Durant el viatge de Kal-El a velocitats relativistes properes a la de la llum, el temps mesurat pels rellotges de Kriptó és de l'ordre d'11 milions d'anys, mentre que per als rellotges de la nau -incloent-hi els rellotges biològics de Kal-El- el temps mesurat (temps propi) només és de 3 anys. Kal-El podria haver fet el viatge en els temps anteriorment indicats si la nau hagués viatjat al $99,999999999999 \%$ de la velocitat de la llum. Un valor increïble però possible dins el marc de la teoria de la relativitat restringida.

\section{Els viatgers del temps: De quan dius que véns?}

"Fue hoy, a las diez, cuando la primera de todas las máquinas del tiempo comenzó su carrera. Le di el último toque, probé todos los tornillos de nuevo, eché una gota de aceite más en la varilla de cuarzo y me senté en el sillín. Cogí la palanca de arranque con una mano y la del freno con la otra, apreté la primera, y casi inmediatamente la segunda. Me pareció que me tambaleaba. Tuve la sensación de caer como en una pesadilla $y$, mirando alrededor, vi el laboratorio exactamente como antes. ¿Había ocurrido algo? Por un momento sospeché que la inteligencia me habia engañado. Luego observé el reloj. Un momento antes, al parecer, habi marcado un minuto o asi después de las diez, iy ahora eran casi las tres y media!". (WELLS, 2001).

Aquest fragment correspon a La máquina del tiempo, relat que el prolífic escritor H. G. Wells va escriure l'any
1895 i que posteriorment es portà a la pantalla amb El tiempo en sus manos (The Time Machine, 1960). Resulta curiós que l'estrena de la versió moderna de La máquina del tiempo (The Time Machine, 2001), va ser dirigida pel besnét de l'escriptor, Simon Wells.

El desig de viatjar en el temps ha fet que s'hagin dissenyat curioses máquines del temps. Així, a L'an Deux Mile Quatre Cent Quarante, una novel.la de Louis Sébastien Mercier, escrita l'any 1771, el protagonista desperta al segle XXV, després d'una migdiada de set segles! A El reloj que marchaba hacia atrás, novel.la d'Edward P. Mitchell escrita el 1881, el simple moviment en sentit contrari del rellotge permet viatjar en el temps. Superman (Superman, the movie. 1978) inverteix la fletxa del temps fent que la Terra giri en sentit contrari. Així salva la seva estimada (Lois Lane) del fatal destí inicial al qual l'havien condemnada els guionistes. Si el mètode emprat per Superman fos viable, el cicle de vida dels suposats venussians s'iniciaria a la tomba i acabaria amb el naixement, perquè Venus gira en sentit retrògrad a la resta de planetes del sistema solar. A En algún lugar del tiempo (Somewhere in Time, 1980) el protagonista del film es converteix en viatger del temps pel simple fet de concentrar-se mentalment. Però la màquina del temps més impressionant de totes és la que es descriu a la novel.la de P. Arthur: The Hero Equation (1959). Un professor inventa una equació que li permet viatjar pel temps pel simple fet de pensar en ella!

L'any 1995, 5000 milions de persones moren a causa d'un virus mortal. Els supervivents abandonen la superfície del planeta Terra i viuen en un complicat món soterrani. Els científics d'aquest món de l'any 2025 desenvolupen una tecnologia que els permet viatjar en el temps ( 12 monos [Twelve Monkeys, 1995]). El protagonista és enviat al passat (1996) per recollir informació sobre el virus amb l'objectiu de millorar les condicions de vida del seu present (2025). En el seu retorn al passat es produeix un error i és enviat al 1990, on s'enamora perdudament d'una psiquiatra de la institució mental on el tenen reclòs.

De tornada al seu present (2025) eludeix una nova missió pels corredors del temps i decideix tornar al passat de 1996 per retrobar-se amb la seva estimada. La cita el porta a l'aeroport d'Orly (París), on és mort per un dels viatgers del temps que vol impedir la seva fugida. Abans de morir comprèn el record que el torturava contínuament: Un jo més jove contempla la seva pròpia mort.

Un dels problemes que afronta la regressió al passat és la possible violació del principi de causalitat: si un temponauta invertís la fletxa del temps i retornés al passat, la seva presència podria alterar el curs de la 


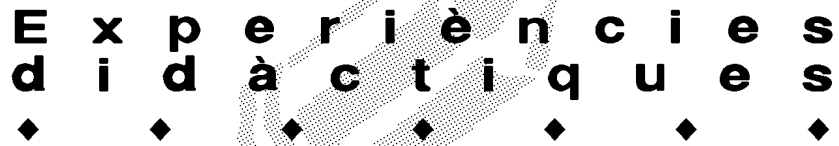

història. Un incident inesperat podria fer que els seus propis pares no arribessin mai a conèixer-se, i impossibilitar el seu posterior naixement. Aleshores, com una persona que no ha pogut néixer ha estat capaç d'alterar el curs dels esdeveniments futurs? Aquest principi de causalitat estableix que els viatgers al passat no poden alterar el curs de la història, només poden ser observadors passius.

A 12 monos no es viola aquest principi, perquè el viatger al passat només vol recollir informació sobre el virus mortal per millorar les condicions de vida del seu present: l'any 2025. I quan el protagonista -interpretat per Bruce Willis- és a punt de matar el portador del virus, un viatger del temps el mata a ell. Així no s'altera el curs de la història.

Una qüestió interessant que es planteja a 12 monos és que el viatger del temps queda atrapat entre l'any 1996 (quan mor el protagonista-adult) i el 2025 (quan el protagonista-adult retorna al passat de 1996). De fet no hi ha cap paradoxa en aquest plantejament, ja que al 1996 existeix un protagonista-nen capaç d'arribar al 2025 de forma natural. L'interessant és que aquesta franja temporal en la qual es veu condemnat a viure el

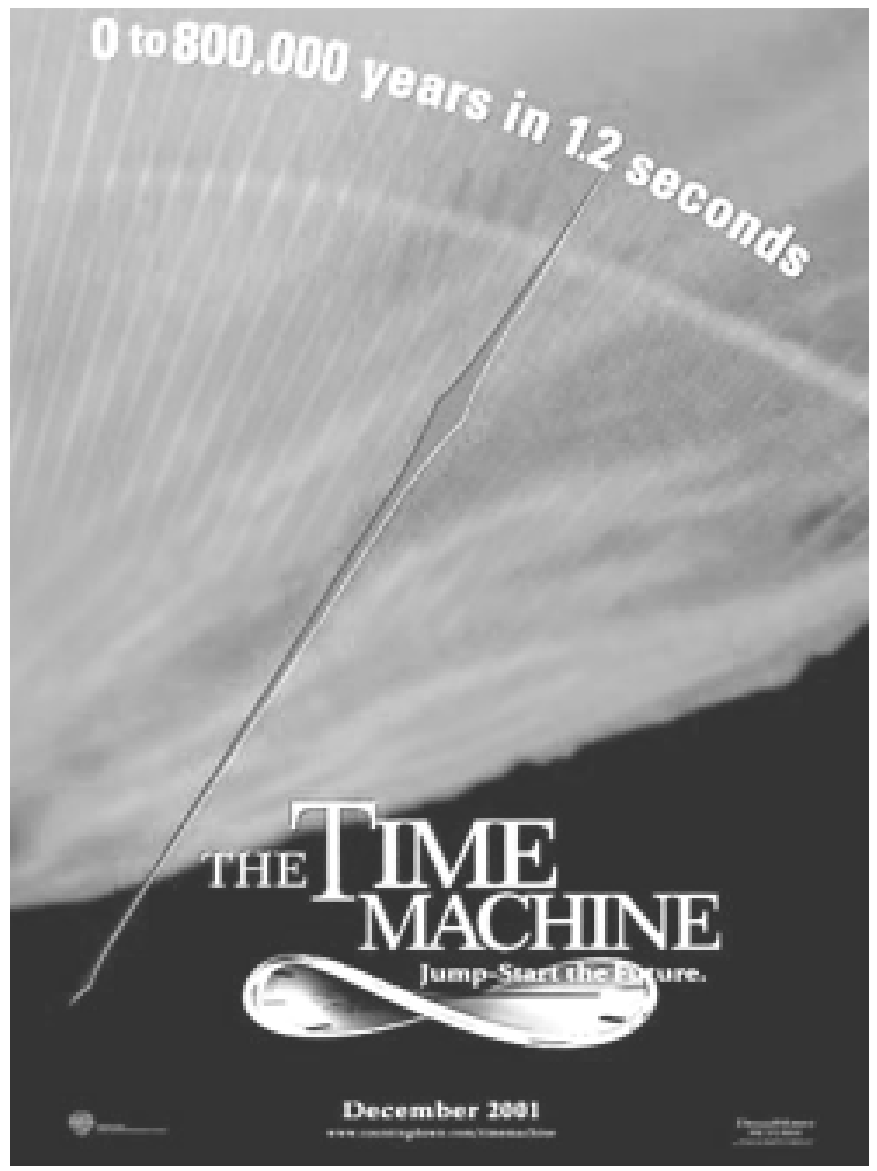

protagonista, fa que assoleixi una immortalitat limitada per ambdues dates.

El temponauta de 12 monos provoca una violació del principi de conservació de la massa-energia. Aquest principi diu, de forma planera, que la massa-energia de l'univers roman constant. En abandonar l'època del seu present (2025), l'univers present perd massa mentre que l'univers de destí (1996, el passat) la incrementa. Això vol dir que les incursions temporals no organitzades són impossibles. Un viatge d'aquesta mena requereix un intercanvi sincronitzat de turistes de la mateixa massa entre ambdues èpoques. En el supòsit que es pogués aconseguir aquest intercanvi, es planteja un problema addicional: com es pot enviar el turista del passat al futur si al passat no tenim màquines del temps? Ens l'envien des del futur? Aquest últim aspecte s'ignora a 12 monos, ja que es veu la màquina del temps que l'envia al passat (1996) però no hi ha cap màquina, al passat, que el retorni al futur (2025).

Tant si tenim màquines com si no, caldrà que l'agència de viatges del futur es posi en contacte amb la del passat, per tal de sincronitzar l'intercanvi de turistes entre les dues èpoques. Com ho fem, telefonant? No!, perquè telefonar o enviar qualsevol senyal electromagnètic equival a transmetre energia. La qüestió resulta irresoluble.

Sembla que els viatges al passat i els viatges bidireccionals al futur estan enfrontats amb les lleis $i$ teories físiques per les violacions que comporten. De fet, un argument que aporten els detractors dels viatges en el temps es basa en la idea que mai no hem estat visitats per temponautes del futur. Però allò que sembla impossible esdevé possible si fem el que li diu l'Uber Morlock (interpretat per un fascinant i magnètic Jeremy Irons) al professor Alexander Hartdegen (el viatger del temps de la nova versió de $L a$ máquina del Tiempo [The Time Machine, 2001]), a les escenes finals de la pel.lícula: "Tots tenim màquines del temps al nostre abast. Les que ens porten enrere es diuen records, i les que ens porten endavant s'anomenen somnis". Bons viatges a tothom!

\section{Referències bibliogràfiques}

JOSÉ, J. i MORENO, M. Física i ciència-ficció. Edicions UPC. 2a ed. Barcelona. 1996.

MORENO, M. i JOSÉ, J. De King Kong a Einstein. La física de la ciencia ficción. Edicions UPC. Barcelona. 1999.

SALVAT, A. Un viatge pel cinema de ciència ficció. A L'aventura de fer ciència. Sisena Setmana de l'Ensenyament. Terrassa. 4-10 maig 2002. p. 33-48.

WELLS, H.G. El hombre invisible. Ed. Planeta. Barcelona. 1985 .

WELLS, H.G. La máquina del tiempo y otros relatos. Ed. Valdemar. Madrid. 2001. 